\title{
Kemampuan Komunikasi Matematis Ditinjau dari Gender Siswa
}

\author{
Hilda Hakim ${ }^{1}$, Leni Agustina Daulay ${ }^{2}$, Maya Listari ${ }^{3}$ \\ 1,2,3 Prodi Pendidikan Matematika, IAIN Takengon, Jln. Yos Sudarso No. 10 Takengon \\ Email: hildahakim@iaintakengon.ac.id
}

\begin{abstract}
ABSTRAK
Salah satu masalah penting dalam pembelajaran Matematika di Indonesia saat ini adalah perkembangan kemampuan komunikasi matematis siswa. Pengembangan komunikasi merupakan salah satu tujuan pembelajaran Matematika dan merupakan salah satu standar kompetensi lulusan Matematika. Di Indonesia, penilaian keterampilan komunikasi meliputi kemampuan siswa untuk mempresentasikan dan menginterpretasikan ide-ide Matematika secara lisan, tertulis atau demonstrasi. Indikator kemampuan komunikasi dalam bentuk tulisan adalah (1) drawing; (2) mathematical expression; (3) written texts. Perbedaan jenis kelamin (gender) tentu menyebabkan perbedaan psikologis dalam belajar, sehingga siswa laki-laki dan perempuan tentu memiliki perbedaan dalam kemampuan memahami dan berkomunikasi. Jenis penelitian yang digunakan adalah penelitian kuantitatif dengan pendekatan deskriptif. Hasil penelitian menunjukkan bahwa pada dasarnya siswa perempuan lebih akurat dan mendetail sedangkan siswa laki-laki lebih kritis dalam berbagai penafsiran. Terdapat perbedaan antara rata-rata nilai yang diperoleh siswa laki-laki dengan siswa perempuan. Ini menunjukkan bahwa kemampuan komunikasi matematis siswa perempuan lebih baik dibandingkan dengan siswa laki-laki, dengan skor rata-rata peremupuan 83,1 dibandingkan dengan skor rata-rata komunikasi matematik laki-laki yaitu 75,7 dengan perbedaan sebesar 7,4\%.
\end{abstract}

Kata kunci: Komunikasi matematis, gender, perbedaan kemampuan.

\begin{abstract}
One of the problems the important thing in learning Mathematics in Indonesia today is the development of students' mathematical communication skills. Communication development is one of the objectives of learning Mathematics and is one of the competency standards for Mathematics graduates. In Indonesia, the assessment of communication skills includes students' ability to present and interpret Mathematical ideas orally, in writing or in demonstration. Indicators of communication skills in written form are (1) drawing; (2) mathematical expressions; (3) written texts. Differences in gender (gender) certainly cause psychological differences in learning, so that male and female students certainly have differences in the ability to understand and communicate. The type of research used is quantitative research with a descriptive approach. The results showed that basically female students were more accurate and detailed while male students were more critical in various interpretations. There is a difference between the average scores obtained by male students and female students. This shows that the mathematical communication ability of female students is better than that of male students, with an average score of 83.1 for female students compared to an average score for male mathematical communication of 75.7 with a difference of $7.4 \%$.
\end{abstract}

Keywords: Mathematical communication, gender, ability difference 


\section{A. Introduction}

Mathematics is not just a tool for thinking, but Mathematics is also a social activity in learning Mathematics, namely as a vehicle for interaction between students, and as a communication tool between teachers and students. When students are challenged with their thinking about Mathematics and present the results of their thinking orally or in writing, they learn to explain and convince. Listening to other students' explanations gives students the opportunity to grow their understanding (NCTM, 2000). Various sources also mention the important role of communication in learning Mathematics (Pugalee, 2001; Freeman, 2013; Yuniara et al, 2018)

Baroody (1998) states that mathematical communication has several aspects that must be met including the ability to present, listen, read or understand, discuss, and write down mathematical ideas into the language of mathematics. The way to transfer communication can be verbally or in writing (Nofrianto et al, 2017). This is in line with NCTM (2014) which states that mathematical abilities can develop when students are actively involved in sharing ideas and ideas in solving mathematical problems.

One of the important problems in learning Mathematics in Indonesia today is the development of students' mathematical communication skills. Communication development is one of the objectives of learning Mathematics and is one of the competency standards for Mathematics graduates. Through learning Mathematics, students are expected to be able to present ideas with symbols, tables, diagrams, or other media to explain situations or problems (Permendikbud, 2006).

In Indonesia, assessment of communication skills includes students' ability to present and interpret mathematical ideas orally, in writing or in demonstration (Depdiknas, 2003). Therefore, this communication-related competence must be achieved during the learning process in the classroom. Effective communication is more than just pronunciation, intonation, or articulation. Communication also involves classroom discourse and teacher interaction (Kirst, 2017) which deepens thinking to help students internalize and process subject content. So, it can be concluded that mathematical communication consists of oral and written communication skills, oral communication such as explaining, conveying ideas or convincing opinions. While written communication is expressing mathematical ideas with pictures/tables, diagrams, symbols mathematically.

Communication skills are essential for problem solving, modeling and reasoning. Mathematical communication competence consists of, first, the ability to learn and interpret written, spoken, or visual mathematical expressions or texts of others. Second, it consists of the ability to express oneself in different ways and at different theoretical or technical levels about mathematical problems, again either in written, spoken, or visual form (Weng \& Jankvist, 2018). The learning process is expected to provide opportunities for students to learn independently according to the abilities of each student, because student learning outcomes are the responsibility of the students themselves (DePorter, 2000). This means that student learning outcomes are directly influenced by student learning experiences and the factors that support it.

Many factors determine the success of students' mathematics learning, including student psychology (Nugraha \& Pujiastuti, 2019). Differences in gender (gender) certainly cause psychological differences in learning, so that male and female students certainly have differences in the ability to understand and communicate. The ability to learn by gender has become the subject of recent research. Globally, gender differences, girls tend to outperform boys in reading, while boys tend to outperform girls in Mathematics (Pitchford et al, 2019). The results of another study, significantly more boys than girls who get the highest score in Mathematics achievement. At the junior and senior secondary school levels, boys perform significantly better than girls, with differences in achievement increasing at the high school (Zhu et al., 2018). On the other hand, Azhari (2018) with the results of his study states that the written mathematical communication skills of male subjects tend to use unordered steps, many scribbles, write answers that are only important, and do not pay attention to aesthetics. While the female subject tends to use sequential and systematic steps, writing. writing is neat and clear, almost no scribbles, and writing answers quite completely. Contrary to the above study, Ajai's (2015) research results conclude that student achievement and retention in algebra does not depend on gender, but on the function of the method. 
Based on the above, mathematical communication skills need to be developed both by teachers and students themselves because gender also affects mathematical ability. Therefore, the purpose of this study is to describe the differences in students' mathematical communication skills in terms of gender.

\section{B. Methods}

The type of research used is quantitative research with a descriptive approach. Descriptive research is a research method that seeks to describe the object or subject being studied objectively, and aims to describe the facts systematically and the characteristics of the object and the frequency of the research accurately (Zellatifanny \& Mudjiyanto, 2018). The population in this study were all students of class $\mathrm{X}$ at SMA Negeri 1 Putri Betung totaling 90 students. Determination at this stage is based on the consideration that the person who gets the information needed is related to the research. The samples in this study were all students of class $\mathrm{X}$ $\mathrm{IPA}_{1}$ totaling those 21 students. The instrument used is a test that refers to mathematical communication indicators. The preparation of the test kit is carried out with the following steps: restrictions on the material being tested; determine the time allotted; determine the number of questions; determine the type of question. The communication skills tested are written communication skills. Chai (1996), stated that the indicators of communication skills in written form are (1) drawing; (2) mathematical expressions; (3) written texts.

\section{Results and Discussion}

The flow of this research consists of four steps, namely observation, test and reflection, and conclusions. The results of the normality test of the learning outcomes of each gender were normal, with the analysis using the second alternative, using the significance coefficient price. The score of female students was $0.687>$ 0.05 , and male students were $0.851>0.05$. Based on the results of the research that has been carried out, the results of the research are shown in Table 1.

Table 1. Results of Descriptive Statistics

\begin{tabular}{|l|c|c|c|c|}
\hline Gender & Total & $\begin{array}{c}\text { Average } \\
\underline{x}\end{array}$ & $\begin{array}{c}\text { Hig } \\
\text { hest }\end{array}$ & $\begin{array}{c}\text { Score Lowest } \\
\text { Score }\end{array}$ \\
\hline Male & 10 & 75.7 & 74 & 63 \\
\hline Female & 11 & 83.1 & 88 & 75 \\
\hline
\end{tabular}

There is a difference between the average value obtained by male students with female students. This shows that the mathematical communication ability of female students is better than that of male students, with an average score of 83.1 for female students compared to an average score for male mathematical communication of 75.7 .

The results showed that basically female students were more accurate and detailed while male students were more critical in various interpretations. Boys are less accurate and detailed in paying attention to something and male students tend to be more critical so that they can distinguish which parts are important and which parts are not important. So, from the results of research on mathematical communication skills, female students are better than male students. The details of the students' communication ability test results are as shown in Table 2.

Table 2. The Score of Male and Female Communication Skills

\begin{tabular}{|c|c|c|c|c|c|c|}
\hline $\begin{array}{l}\mathrm{N} \\
\mathrm{O}\end{array}$ & Aspect & Indicator & $\frac{x}{\mathrm{LK}}$ & $\frac{x}{\mathrm{PR}}$ & $\begin{array}{c}\% \\
\text { LK } \\
\text { score }\end{array}$ & $\begin{array}{c}\% \\
\text { PR } \\
\text { score }\end{array}$ \\
\hline 1 & Drawing & $\begin{array}{l}\text { Expressing a } \\
\text { situation in the } \\
\text { form of a } \\
\text { picture and } \\
\text { solving it }\end{array}$ & $\begin{array}{c}45 . \\
9\end{array}$ & 60.6 & 44.8 & 66.3 \\
\hline 2 & $\begin{array}{l}\text { Mathem } \\
\text { atical } \\
\text { expressi } \\
\text { on } \\
\text { Expressi } \\
\text { ng a } \\
\text { mathem } \\
\text { atical }\end{array}$ & $\begin{array}{l}\text { situation or } \\
\text { idea in the } \\
\text { form of a } \\
\text { mathematical } \\
\text { symbol or } \\
\text { model and } \\
\text { solving it }\end{array}$ & $\begin{array}{c}52 . \\
8\end{array}$ & $\begin{array}{c}54 \\
, 3\end{array}$ & 48,3 & 50.9 \\
\hline 3 & Writing & $\begin{array}{c}\text { State and } \\
\text { explain a } \\
\text { mathematical } \\
\text { picture or } \\
\text { model in the } \\
\text { form of a } \\
\text { mathematical } \\
\text { idea. }\end{array}$ & $\begin{array}{c}60 . \\
6\end{array}$ & 54.6 & 55.5 & 42.9 \\
\hline
\end{tabular}

The conclusion that can be drawn from Table 2 is the aspect of drawing, the average score for males is 45.9 and for females is 60.6. The indicators of drawing here include linking images into mathematical ideas. The following is Figure 1 which is a woman's answer to the drawing indicator. 


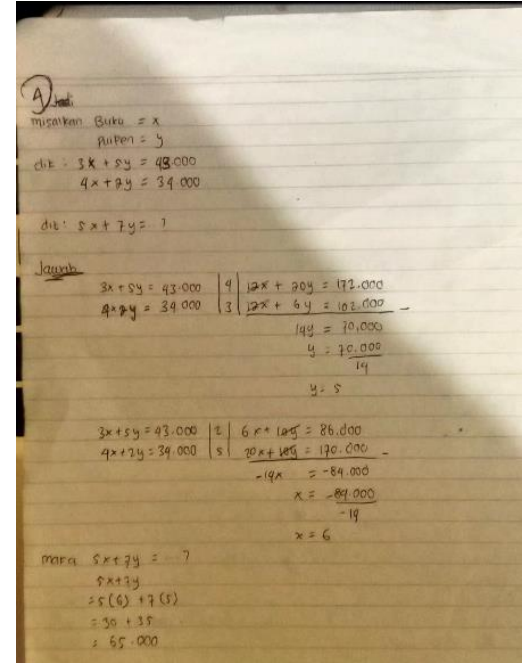

Figure 1. Answers

Figure 1 shows that female students understand what is meant by the question, they are able to answer with the specified steps. The women's answers were more thorough and detailed, starting from the preparation of the initial steps to the final completion. This agrees with the results of research (Nugraha \& Pujiastuti, 2019) that the indicator component completes a higher value than stating a mathematical situation or idea in the form of a mathematical symbol or model. This can be seen from the results of the answers of female students who tend to prioritize solving through their own way by ignoring the components in expressing a mathematical situation or idea in the form of symbols or mathematical models.

Aspects of mathematical expression, the average score for men and the average value for women only has a gain of 1.8. This shows that the indicator states a mathematical situation or idea in the form of a mathematical symbol or model and the solution between male and female students is almost the same. Figure 2 shows the results of male and female answers for aspects of mathematical expression.

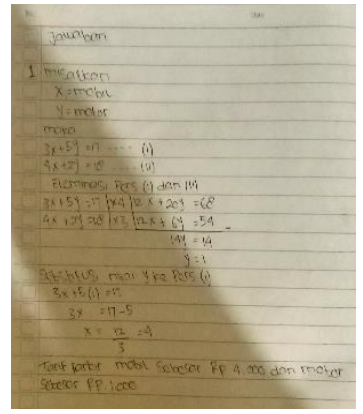

(a)

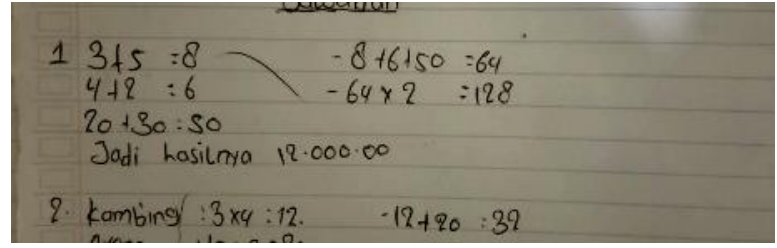

(b)

Figure 2. (a) female answers, (b) male answers

Based on the students' answers, the female students' answers seemed more correct than the male students' answers. Female students better understand the mathematical search system with the required steps while male students work on problems in a simple way without including any steps that must be done as we can see in Figure 4.8 the answers of male students look so simply. In this problem, students are asked to determine the price of cars and motorbikes in everyday life problems using the combined method (substitution and elimination). While in the writing aspect, the indicators seen are stating and explaining a picture or mathematical model in the form of a mathematical idea. From table 2, it can be seen that the average score of men is higher than that of women, namely 60.6 and $55.5 \%$, while women's scores are 54.6 and $42.9 \%$. This is in line with the results of Prayitno's (2013)s research, that the mathematical communication of junior high school students in solving tiered math problems in terms of gender differences, the mathematical ability of male subjects is superior in writing more completely and accurately, while female subjects are more clearly presented verbally and verbally. In addition, the results of research with different opinions from a gender perspective show that not always male students have better writing skills than girls or girls have better verbal communication skills than boys (Firdiani et al, 2020). Other studies have also shown that selfconfidence is more favorable for boys, and the perception of mathematics as a male domain begins to develop at around 13 years of age, with boys associating good performance with intelligence or skill and girls with effort and obedience (Ursini \& Sánchez, 2008; Graf et al., 2012). Gender performance in mathematics has also been investigated on a large scale in two ways: First, through mathematics assessments conducted by thousands of students, for example, PISA and TIMSS, and college entrance examinations. in the US and general examinations in the UK. Second, with a meta-analysis that collects data from smaller research studies in 
laboratories and schools (Smith, 2014). The difference in the results of research on mathematical ability in terms of gender conducted internationally and nationally needs to be done repeatedly, this provides evidence that researchers have tested and refined hypotheses over time act.

\section{Conclusions}

Based on the results of data collection and analysis, it is concluded that there are differences in mathematical communication skills in terms of student gender, where female students have better mathematical communication skills compared to male students' mathematical communication skills with a difference of $7.4 \%$. Aspects of drawing, with the indicator that students are able to express a situation in the form of pictures and solve it, female students have higher scores with a difference of $21.5 \%$. Aspects of mathematical expression indicators that students are able to express a situation or mathematical idea in the form of symbols or mathematical models and solve it female students have higher scores than male students although only $2.6 \%$ differ. In contrast to the two previous aspects, in the writing aspect, with the indicator that students are able to state and explain a mathematical image or model in the form of a mathematical idea, the scores for males are higher than females with a difference of $12.6 \%$.

\section{E. References}

Ajai, J. T., \& Imoko, B. I. (2015). Gender differences in mathematics achievement and retention scores: A case of problem-based learning method. International Journal of Research in Education and Science, 1(1), 45-50. https://doi.org/10.21890/ijres.76785

Azhari, D. N., Rosyana, T., \& Hendriana, H. (2018). Analisis Kemampuan Komunikasi Matematis Siswa Smp Berdasarkan Gender Dan Self Concept. JPMI (Jurnal Pembelajaran Matematika Inovatif), I(2), 129.

https://doi.org/10.22460/jpmi.v1i2.p129138

Baroody, A., Baroody, A. J., \& Coslick, R. T. (1998). Fostering children's mathematical power: An investigative approach to $K-8$ mathematics instruction. Routledge.

Cai, J., Jakabcsin, M. S., \& Lane, S. (1996).
Assessing Students Mathematical Communication. School Science and Mathematics, 96(5), 238-246. https://doi.org/10.1111/j.1949-

8594.1996.tb10235.x

Depdiknas. (2003). Undang-undang Republik Indonesia Nomor 20 Tahun 2003 tentang Sistem Pendidikan Nasional. 1, 6-8. https://doi.org/10.16309/j.cnki.issn.10071776.2003.03.004

DePorter, B. (2000). Quantum teaching. PT Mizan Publika.

Firdiani, N. H., Herman, T., \& Hasanah, A. (2020). Gender and mathematical communication ability. Journal of Physics: Conference Series, 1521(3), 458-465. https://doi.org/10.1088/1742$6596 / 1521 / 3 / 032095$

Freeman. (2013). Membangun Kemampuan Komunikasi Matematis Mahasiswa Pada Mata Kuliah Konsep Dasar Matematika Sd Prodi Pgsd. Journal of Chemical Information and Modeling, 53(9), 16891699.

Graf, N. B., Palacios, fatima F., \& Everardo, M. rios. (2012). Investigation Feminista Epistemologia Y Representationes Sociales. In Metodología de la investigación; Estudios de género; Investigación; Feminismo; Representaciones sociales; América Latina.

Kirst, W. M. (2017). Oral Communication Skills Are Important for Students. Standfort University.

https://collegepuzzle.stanford.edu/oralcommunication-skills-are-important-forstudents/

NCTM. (2014). Principles to Actions: Ensuring Mathematical Success for All.

Nofrianto, A., Maryuni, N., \& Amri, M. A. (2017). Komunikasi matematis siswa: pengaruh pendekatan matematika realistik. Jurnal Gantang, 2(2), 113-121.

Nugraha, T. H., \& Pujiastuti, H. (2019). Analisis Kemampuan Komunikasi Matematis Siswa Berdasarkan Perbedaan Gender. Edumatica : 
Jurnal Pendidikan Matematika, 9(1), 1-7. https://doi.org/10.22437/edumatica.v9i1.58 80

Permendikbud, R. (2006). Peraturasn Menteri Pendidikan Nasional RI Nomor 23 Tahun 2006. 1-21.

Pitchford, N. J., Chigeda, A., \& Hubber, P. J. (2019). Interactive apps prevent gender discrepancies in early-grade mathematics in a low-income country in sub-Sahara Africa. Developmental Science, 22(5), 1-14. https://doi.org/10.1111/desc. 12864

Prayitno, S., Suwarsono, S., \& Siswono, T. Y. E. (2013). Komunikasi matematis siswa SMP dalam menyelesaikan soal matematika berjenjang ditinjau dari perbedaan gender. Prosiding FMIPA UNY, 384-389.

Pugalee, D. (2001). Using Communication To Develop Students' Mathematical Literacy. Mathematics Teaching in the Middle School, 6.

Smith, C. (2014). Gender and participation in mathematics and further mathematics Alevels: a literature review for the Further Mathematics Support Programme. IOE Supporting Advanced Mathematics Project, September 2014.

Ursini, S., \& Sánchez, G. (2008). Gender, technology and attitude towards mathematics: A comparative longitudinal study with Mexican students. ZDM International Journal on Mathematics Education, 40(4), 559-577. https://doi.org/10.1007/s11858-008-0120-1

Weng, P., \& Jankvist, U. T. (2018). Communication competency as an indicator for mathematical giftedness. December, 112.

Yuniara, P., Sinaga, B., \& Dewi, I. (2018). Analysis Of Difficulties In Completing Mathematical Communication Problem Solving In Terms Of Learning Styles Using Inquiry Learning. 200(Aisteel), 764-768. https://doi.org/10.2991/aisteel-18.2018.166

Zellatifanny, C. M., \& Mudjiyanto, B. (2018). the
Type of Descriptive Research in Communication Study. Jurnal Diakom, 1(2), 83-90.

Zhu, Y., Kaiser, G., \& Cai, J. (2018). Gender equity in mathematical achievement: the case of China. Educational Studies in Mathematics, 99(3), 245-260. https://doi.org/10.1007/s10649-018-9846-z 